\title{
La legislación general acerca de los judíos en el reinado de Juan II de Castilla*
}

\author{
General legislation concerning Jews \\ during the reign of Juan II of Castile
}

EnRIQue Cantera Montenegro**

\begin{abstract}
RESUMEN
En este artículo se analiza la legislación general promulgada a lo largo del reinado de Juan II de Castilla (1406-1454) en relación con los judíos. La gran extensión de este reinado, los vaivenes que marcaron la política castellana en este momento y la proximidad cronológica de las persecuciones de 1391, que tanta incidencia tuvieron en la evolución del judaísmo hispano, hacen de él un escenario idóneo para analizar las complejas circunstancias, de muy diversa naturaleza-política, económica, social, religioso-ideológica-, que en la primera mitad del siglo XV concurrían en el reino de Castilla en la cuestión judía. Resulta particularmente interesante y revelador el estudio del posicionamiento de la monarquía en relación con los judíos, con el trasfondo de la revuelta nobiliaria.
\end{abstract}

PALABRAS CLAVE Juan II, Álvaro de Luna, Judíos, Reino de Castilla, Siglo XV.

\begin{abstract}
This article examines the general legislation enacted throughout the reign of Juan II of Castile (1406-1454) with respect to the Jews. The considerable length of his reign, the ups and downs that characterized Castilian politics in this period and the chronological proximity to the persecutions of 1391 which severely altered the evolution of Hispanic Judaism make it an ideal setting to analyse the complex circumstances of very diverse origin-political, economic, social, religious-ideological- which affected the Jewish question in Castile in the first half of the fifteenth century. The monarchy's stance with respect to the Jewish community in the context of the uprising of the nobility is particularly interesting and revealing.
\end{abstract}

\section{KEY WORDS}

Juan II, Álvaro de Luna, Jews, Kingdom of Castile, Fifteenth century.

* Fecha de recepción del artículo: 2011-11-14. Fecha de aceptación del artículo: 2011-12-12.

Este trabajo se realiza en el marco del Proyecto de Investigación titulado El ejercicio del poder en Castilla en la primera mitad del siglo XV, financiado por el Ministerio de Ciencia e Innovación (Referencia: HAR2009-09912 - Subprograma HIST).

** Departamento de Historia Medieval y Ciencias y Técnicas Historiográficas. UNED. C.e.: ecantera@geo.uned.es 


\section{PRECEDENTES}

Desde mediados del siglo XIII, y a lo largo de toda la Baja Edad Media, las Cortes se transformaron en una plataforma más del creciente antijudaísmo que se manifestaba en la sociedad castellana, y las peticiones de los procuradores de las ciudades y villas del reino y las disposiciones acordadas en ellas, pese a su carácter reiterativo, permiten observar la evolución en la actitud social hacia los judíos y el posicionamiento de la autoridad pública. Entre 1252 y 1350 se celebraron treinta y dos sesiones de Cortes en Castilla, y en veintiocho de ellas se abordó, en mayor o menor medida, la cuestión judía, en tanto que en ocho de las quince reuniones celebradas entre 1367 y 1391 fueron también presentadas reclamaciones contra los judíos ${ }^{1}$; los asuntos tratados de forma habitual son los relativos a la regulación de los contratos de préstamo con interés, al desempeño de oficios y cargos públicos por parte de los judíos, a sus propiedades inmuebles, a la posibilidad de disponer de «alcaldes apartados» ${ }^{2}$ y a las pruebas testificales en pleitos mixtos entre cristianos y judíos. Por el contrario, hasta el último tercio del siglo XIV las referencias a medidas de segregación social, tales como el apartamiento de los judíos en barrios propios y el uso de señales identificativas externas, fueron de carácter marginal ${ }^{3}$.

El tratamiento que en las sesiones de Cortes se hace de la cuestión judía permite hacer un seguimiento bastante fiel de la evolución del «problema judío» en la Castilla de la Baja Edad Media. Así, y en comparación con las disposiciones adoptadas en reuniones de Cortes de mediados del siglo XIII, como las de Valladolid de 1258 o las de Jerez de 1268, en las que se hace hincapié en cuestiones tradicionales en las relaciones entre cristianos y judíos, con disposiciones que limitan las relaciones de convivencia entre miembros de uno y otro colectivos, que prohíben a los judíos el uso de

\footnotetext{
1 Véanse sobre este particular los trabajos de Pilar LEÓN TELLO, «Legislación sobre judíos en las Cortes de los antiguos reinos de León y Castilla», en Proceedings of the Fourth World Congress of Jewish Studies. 4th. Jerusalem, 1965, vol. 2, págs. 55-63, José María MONSALVO ANTÓN, «Cortes de Castilla y León y minorías", en Las Cortes de Castilla y León en la Edad Media. Valladolid. Cortes de Castilla y León, 1988, 2 vols. (en concreto, vol. 2, págs. 143-191), y Fernando SUÁREZ BILBAO, El fuero judiego en la España Cristiana. Las fuentes jurídicas. Siglos V-XV. Madrid. Dykinson, 2000.

2 Así se denomina a los oficiales especiales encargados de conocer en los pleitos relativos a préstamos con interés y a cualquier otra cuestión tocante a las deudas de cristianos con judíos. Acusándoles de proclividad hacia los intereses de los judíos e, incluso, de ser fácilmente sobornables por éstos, desde tiempos del rey Sancho IV los procuradores de las ciudades y villas en Cortes reclamaron insistentemente que los pleitos relativos a las deudas con judíos quedaran sujetos a la jurisdicción común, es decir que fueran competencia de los alcaldes ordinarios, reales o concejiles, suprimiéndose cualquier privilegio que los reyes hubieran podido conceder a los judíos con anterioridad.

3 Pese a que algunas disposiciones conciliares, como las aprobadas en el IV Concilio de Letrán de 1215 o en el Concilio de Vienne de 1311, exigían de las autoridades públicas de territorios cristianos la puesta en práctica de medidas que dificultaran la convivencia de los judíos con cristianos, los reyes de Castilla habían solicitado moratorias en la aplicación o, simplemente, habían buscado excusas para su no aplicación. Pese a que en las Cortes de Palencia de 1313 se solicitó ya formalmente del monarca que se obligara a los judíos a ser portadores de señales identificativas externas, y a que en las Cortes de Burgos de 1367, en las de Toro de 1371, en las de Soria de 1380, en las de Valladolid de 1385 y en las de Briviesca de 1387 se solicitó el apartamiento de los judíos en barrios aislados, los monarcas se resistían a la adopción de tan drásticas medidas.
} 
ropas de calidad y adornos de lujo, y que regulan los préstamos con interés, los cuadernos de Cortes de fines del siglo XIII y de comienzos de la siguiente centuria muestran un considerable incremento de la presión antijudía. Buen ejemplo de ello son las Cortes de Valladolid de 1293, en las que se prohíbe a los judíos tener otras propiedades inmuebles que no fueran sus viviendas ${ }^{4}$, o las Cortes de Valladolid de 1295, en las que los procuradores de las ciudades solicitan la exclusión de los judíos de las tareas de recaudación de rentas reales, una solicitud que fue reiterada en las Cortes de Medina del Campo de 1302 y en las de Valladolid de 1307, como muestra más evidente de que el monarca no había cedido a la presión ciudadana.

Del mismo modo, las Cortes de la segunda mitad del siglo XIV muestran que las relaciones entre cristianos y judíos se habían deteriorado de forma considerable, poniendo en evidencia un notable incremento de la hostilidad popular hacia éstos. Las peticiones presentadas por los procuradores de las ciudades no dejan lugar a ninguna duda, aun cuando la reiteración en las demandas es, nuevamente, el signo más evidente de que los monarcas seguían resistiéndose a ponerlas en práctica. Las peticiones más relevantes son las siguientes ${ }^{5}$ :

- Anulación de las cartas de deuda en las que los judíos aparecían como acreedores, al considerar usurarios y fraudulentos todos los contratos: Cortes de Toro de 1369, de Burgos de 1376 y 1377, y de Valladolid de 1385.

- Prohibición de que los judíos ejercieran cargos y oficios en la administración regia, principalmente en cuestiones hacendísticas: Cortes de Burgos de 1367, de Toro de 1371 y de Valladolid de 1385.

- Apartamiento de los judíos en barrios especiales: Cortes de Burgos de 1367, de Toro de 1371, de Soria de 1380, de Valladolid de 1385 y de Briviesca de 1387.

- Supresión de la capacidad jurisdiccional de las aljamas judías, así como de los oficiales propios de las comunidades hebreas: Cortes de Toro de 1371, de Burgos de 1379, de Soria de 1380 y de Valladolid de 1385.

Sin embargo, y de forma muy significativa, después de 1391, y hasta el Ordenamiento de Valladolid de 1405, desaparecen las referencias a los judíos en los cuadernos de las siete sesiones de Cortes celebradas en este arco cronológico, lo que es atribuido por Amador de los Ríos a la debilidad extrema en la que quedó la población judía castellana después de las persecuciones de 1391, que haría innecesaria la reglamentación de su situación legal ${ }^{6}$. Por el contrario, la promulgación del Ordena-

\footnotetext{
4 Esta disposición, que tenía como objetivo impedir que los judíos pudieran llegar a convertirse en propietarios de tierras de labor, fue reiterada en las Cortes de Cuéllar de 1297 y en las de Madrid de 1329.

5 Según Fernando SUÁREZ BILBAO, El fuero judiego en la España Cristiana. Las fuentes jurídicas. Siglos V-XV, págs. 106-107.

6 José AMADOR DE LOS RÍOS, Historia social, política y religiosa de los judíos de España y Portugal. Madrid, 1875, vol. II, pág. 418-419. Es también interesante a este respecto el capítulo décimo del volumen II de esta obra de Amador de los Ríos, titulado «Situación legal de los judíos a principios del siglo XV (1391 a 1438)», págs. 487-526.
} 
miento de Valladolid de 1405 podría responder, en su opinión, a una cierta recuperación de la comunidad judía castellana, explicación ésta que resulta insatisfactoria, ya que no sólo es inverosímil que la comunidad judía se hubiera recuperado de los desastres sufridos en 1391 en tan corto espacio de tiempo, sino que, además, a lo largo de los primeros decenios del siglo XV fueron varias las comunidades judías castellanas que se vieron favorecidas con descuentos en las cantidades que debían satisfacer a la hacienda regia en concepto de «cabeza de pecho», debido a que su población había disminuido considerablemente después de 13917. Parece más plausible la hipótesis que apunta Emilio Mitre, en el sentido de que si en 1391 el rey Enrique III había tenido la fortaleza necesaria para castigar los excesos de los asaltos a las juderías, en 1405, por el contrario, su posición era mucho más débil, a lo que se unía un considerable incremento del descontento popular a causa de la mala situación económica que atravesaba el reino de Castilla8. Qué duda cabe que el impacto que debió producir la violenta explosión antijudía de 1391, unido a la que parecía firme actitud de la monarquía para cortarla de raíz, debió condicionar durante unos años a los procuradores de las ciudades y villas en Cortes quienes, quizá, no estimaron oportuno el momento para insistir en sus tradicionales demandas contra los judíos.

De este modo, transcurrido ya más de un decenio desde las persecuciones de 1391, las Cortes de Valladolid de 1405, convocadas por el rey Enrique III para la jura del príncipe heredero, situaron nuevamente a los judíos en el centro del debate, de forma que los procuradores de las ciudades, villas y lugares elevaron al rey diversas peticiones, quejándose de la actuación de los judíos. La respuesta del Consejo Real a estas peticiones se contiene en el conocido como Ordenamiento de Valladolid de 1405, cuyas disposiciones más relevantes pueden resumirse en los siguientes puntos:

- Prohibición del préstamo con interés, y estricta regulación de los contratos entre cristianos y judíos, que quedan sujetos a severas restricciones, cuya transgresión se castiga con dureza. Incluso se llega a disponer que en los contratos en vigor los deudores cristianos no habrían de pagar al acreedor judío sino la mitad de la deuda, presuponiendo que en el contrato habría

\footnotetext{
7 Todavía en el año 1439 dos de las más importantes aljamas judías del norte peninsular, las de Vitoria y Calahorra, obtuvieron del rey Juan II un considerable descuento en las cantidades que debían pagar a la hacienda regia en concepto de cabeza de pecho, «por quanto los dichos judíos eran pocos e pobres». En el caso de Vitoria la cantidad se redujo de 3.000 maravedíes de la moneda vieja a 4.800 maravedíes de la moneda blanca, lo que equivaldría a unos 2.400 maravedíes de moneda vieja, es decir un descuento del 20 por 100. A los judíos de Calahorra se les redujo la cantidad que debían pagar de 5.202 maravedíes de moneda vieja a 8.000 maravedíes de moneda blanca, lo que equivaldría a unos 4.000 maravedíes de moneda vieja, con un descuento del 24 por 100. (Archivo General de Simancas, Escribanía Mayor de Rentas, Contaduría de la Razón, leg. 1. Fritz BAER, Die Juden im Christlichen Spanien. I/2. Kastilien/Inquisitionakten. Berlín, 1936, págs. 305-306, y Enrique CANTERA MONTENEGRO, Las juderías de la diócesis de Calahorra en la Baja Edad Media. Logroño. Instituto de Estudios Riojanos, 1987, pág. 106).

8 Véanse los trabajos de Emilio MITRE FERNÁNDEZ, «Notas en torno a las disposiciones antijudías de las Cortes de Valladolid de 1405", en Proceedings of the Seventh World Congress of Jewish Studies. History of the Jewish in Europe. Jerusalem, 1981, vol. III, págs. 115-122, y «Los judíos y la Corona de Castilla en el tránsito al siglo XV», en Cuadernos de Historia. Anexos de Hispania, 3 (1969), págs. 347-368.
} 
mediado logro. En contrapartida, y atendiendo a la autorización en tal sentido establecida en el Ordenamiento de Alcalá de 1348, se reconoce a los judíos el derecho a adquirir propiedades inmuebles, en cuantía de hasta 30.000 maravedíes en los territorios situados al norte del Duero y de hasta 20.000 maravedíes al sur de este río.

- Regulación de la personalidad jurídica de los judíos, eliminándose la obligatoriedad de que en los pleitos mixtos entre cristianos y judíos hubiera al menos un testigo judío.

- Restricción en el derecho de propiedad de los judíos, de forma que se revoca el supuesto privilegio de que gozaban y que les permitía no dar explicaciones acerca del origen de los bienes muebles que poseían.

- Obligación para los judíos de llevar sobre sus vestimentas las señales identificativas externas, en particular la rodela de paño bermejo que debían llevar en la parte delantera del hombro derecho; únicamente quedarían eximidos de esta obligación cuando viajaran por caminos, por el peligro de que fueran reconocidos en despoblado y pudieran ser objeto de robo o agresión.

El Ordenamiento de Valladolid de 1405 constituye un hito de importancia en la evolución de la cuestión judía en la Castilla de la Baja Edad Media, tanto por las disposiciones que en él se contienen, particularmente severas para con la población hebrea, como porque se adivina ahora un firme propósito de las ciudades y villas de exigir su estricto cumplimiento. El nuevo repunte del sentimiento antijudío pudo tener su manifestación en algunos brotes violentos, en cualquier caso pocos y muy localizados, como el motín que, al parecer, sufrieron los judíos cordobeses en los últimos meses del año 1405 o en los primeros de 1406, y, especialmente, en la tensión entre cristianos y judíos en torno a los contratos de deuda, pues no fueron pocos los que, amparándose en el Ordenamiento, pretendían una revisión retroactiva de las cartas de deuda, lo que obligó al monarca a aclarar que las disposiciones que en él se contenían no podían aplicarse a contratos resueltos con anterioridad a la convocatoria de las Cortes de $1405^{9}$.

\section{LA PRAGMÁTICA DE LA REINA DOÑA CATALINA DE LANCASTER DE 1412}

La prematura muerte del rey Enrique III en diciembre de 1406 abrió una larga minoría que, muy probablemente, hizo temer a los judíos que pudieran reproducirse los violentos acontecimientos de 1391 pues, no en vano, a lo largo de toda la Edad Media los momentos más críticos para la comunidad hebrea castellana coinciden con vacíos de poder como consecuencia de la muerte del rey o de una minoría; y los judíos no eran ignorantes de ello. Pese a que la firme actuación del regente Fer-

${ }^{9}$ Fernando SUÁREZ BILBAO, El fuero judiego en la España Cristiana. Las fuentes jurídicas. Siglos V-XV, pág. 109. 
nando de Trastámara impidió que estos temores se hicieran realidad, el antijudaísmo derivó hacia la vía doctrinal y legal. Unos años después de la promulgación del Ordenamiento de Valladolid de 1405, el 2 de enero de 1412 era promulgado por la reina madre y regente, Catalina de Lancaster, el «Ordenamiento sobre el encerramiento de los judíos e de los moros», más conocido habitualmente como «leyes de Ayllón». En el año 1411, en uno de sus frecuentes itinerarios de predicación, llegó a la localidad segoviana de Ayllón el dominico valenciano fray Vicente Ferrer, con el fin de entrevistarse con los regentes de Castilla Fernando de Trastámara y Catalina de Lancaster, a quienes quería convencer sobre la conveniencia de limitar las relaciones de convivencia entre cristianos y judíos y la libertad de acción de éstos, para que no se malograran las conversiones recientes de judíos al cristianismo producidas a raíz de las persecuciones de 1391. A lo largo de los últimos años del siglo XIV y los primeros del XV, fray Vicente Ferrer promovió una intensa campaña de predicación en las sinagogas de numerosas localidades hispanas que, al parecer, se saldó con un importante número de conversiones al cristianismo. Su propósito último consistía en lograr la desaparición definitiva del judaísmo de las tierras hispanas, aun cuando, en sintonía con la postura tradicional del Pontificado, insistía en que la conversión de los judíos debería llegar por la vía de la persuasión y en ningún caso mediante el uso de la violencia ${ }^{10}$. Pero, con el fin de animar a los judíos a la conversión y, sobre todo, para evitar que los judeoconversos convertidos recientemente al cristianismo retornaran a la religión judía, se consideraba lícito, y aún deseable, que la legislación civil pusiera serias cortapisas en la libertad de actuación de los judíos. Y éste, y no otro, es el objetivo que guía la promulgación del Ordenamiento de Valladolid de 1412, o Pragmática de la reina doña Catalina, cuya redacción fue encargada al judeoconverso Pablo de Santa María, obispo de Burgos y Canciller Mayor de Castilla desde la muerte de Pero López de Ayala ${ }^{11}$. La Pragmática fue hecha pública el día 2 de enero de 1412, en Valladolid, a donde se había trasladado la corte ${ }^{12}$.

10 La posición del Pontificado en relación con los judíos es claramente perceptible a través de las Decretales, una recopilación de la legislación pontificia encargada por el papa Gregorio IX al dominico catalán Raimundo de Peñafort, quien concluyó la tarea en el año 1234. Un título completo, integrado por diecinueve leyes, del libro $V$ está dedicado a regular las relaciones de cristianos con judíos y musulmanes, y a través de él es fácil comprobar cómo se mantuvo a lo largo del tiempo, sin grandes alteraciones, la tradicional política pontificia hacia los judíos, sustentada en el pensamiento agustiniano (véase el trabajo de Bernhard BLUMENKRANZ, "Augustin et les juifs; Augustin et le judaïsme», en Recherches Augustiniènnes, 1 (1958), págs. 225-241.

11 El historiador Benzion NETANYAHU considera que la intervención del obispo Pablo de Santa María en la gestación de la Pragmática fue bastante más relevante que su mera redacción, y argumenta que tuvo un papel fundamental en su concepción y aprobación (véase su documentado estudio Los orígenes de la Inquisición en la España del siglo XV. Barcelona. Crítica, 1999, págs. 170-179). En cualquier caso, parece fuera de toda duda que Pablo de Santa María estaba plenamente de acuerdo con el programa de fray Vicente Ferrer en relación con los judíos, y es muy probable que actuara como mediador entre los regentes castellanos y el dominico valenciano.

12 El original de la Pragmática se conserva en la sección de Manuscritos de la Biblioteca Nacional de España, así como en la biblioteca de la Real Academia de la Historia, Bulas, Privilegios, Ordenamientos reales del rey Juan II y otras escrituras, tomo 17, fol. 29, pág. 38.

Asimismo se conserva un manuscrito de la Pragmática, del siglo $\mathrm{XV}$, en la Biblioteca del monasterio de El Escorial, Z.I.6, Fol.. 139v-141v. 
La influencia de fray Vicente Ferrer en la redacción del Ordenamiento de Valladolid de 1412 está fuera de toda duda, no sólo porque consta su presencia en la corte castellana, en Ayllón en 1411, sino porque, como ha puesto de relieve Pilar León Tello, se conservan unas ordenanzas murcianas muy similares en su contenido, de las que se da cuenta en las actas del concejo de Murcia, en concreto en la sesión del día 24 de marzo de 1411, que son tituladas de forma bien expresiva Ordenaciones que se hizieron por las palabras del maestro Vicente ${ }^{13}$. También la Crónica del rey Juan II compuesta por Fernán Pérez de Guzmán atribuye a fray Vicente la solicitud a la reina y al infante don Fernando de que se procediera al apartamiento de judíos y moros en barrios aislados.

En opinión de Netanyahu, la Pragmática de doña Catalina contiene las más duras leyes hasta entonces promulgadas contra los judíos en la Cristiandad, con la única excepción de las órdenes de expulsión decretadas en diferentes territorios europeos, y responde a un propósito uniforme y a un programa definido: la conversión de los judíos al cristianismo ${ }^{14}$. Está compuesta por un total de veinticuatro disposiciones, la primera de las cuales es la que da título al Ordenamiento. En ella se ordena que todos los judíos y moros del reino y sus señoríos residan en lugares apartados de los cristianos en todas las localidades en las que habiten, y que esos lugares estén rodeados por una muralla en la que tan sólo se abra una puerta que ponga en comunicación el barrio judío con las restantes colaciones de la ciudad. El apartamiento de los judíos y moros debería llevarse a cabo en el plazo máximo de ocho días desde el momento en el que les fuera señalado el lugar por las autoridades concejiles. El incumplimiento de esta disposición llevaba aparejada para el infractor la pérdida de todos sus bienes y las penas corporales que fueran determinadas por la justicia regia.

La disposición sexta prohíbe a judíos y moros tener en sus barrios plazas o mercados para vender a cristianos productos comestibles, bajo pena de 500 maravedíes.

Otras disposiciones de la Pragmática tienen por objeto impedir o, cuando menos, dificultar las relaciones de convivencia de cristianos con judíos y moros. Así, la disposición cuarta prohíbe a judíos y moros comer y beber en compañía de cristianos, y a los judíos tener escuderos y servidores, amas de cría, yugueros, hortelanos o pastores cristianos; asimismo se prohíbe a judíos y moros asistir a bodas o entierros de cristianos y mantener conversaciones con ellos. La infracción de lo contenido en esta disposición se castiga con pena de 2.000 maravedíes.

En la misma línea, la disposición décima prohíbe a judíos y moros visitar a cristianos enfermos, así como darles medicinas. Asimismo se prohíbe a judíos y moros

13 Pilar LEÓN TELLO, Judíos de Toledo. Madrid. C.S.I.C., 1979, 2 vols. (en concreto, vol. I, pág. 195). Asimismo cita estas ordenanzas Juan TORRES FONTES, «Moros, judíos y conversos en la regencia de Don Fernando de Antequera», en Cuadernos de Historia de España, XXXI-XXXII (1960), págs. 60-97 (en concreto, págs. 93-95).

${ }^{14}$ Benzion NETANYAHU, Los orígenes de la Inquisición en la España del siglo XV, págs. 170-175. 
bañarse en compañía de cristianos y enviarles presentes de comida, haciendo referencia, en concreto, a hojaldres, especias, pan cocido, vino, animales muertos y frutas, todo ello bajo pena de 300 maravedíes para el infractor.

La disposición decimonovena prohíbe a judíos y moros tomar a sueldo o a jornal a cristianos para trabajar sus heredades y para cuidar sus casas.

La disposición undécima prohíbe a las mujeres cristianas, casadas o solteras, e incluso a las prostitutas, entrar en la judería y en la morería, de día o de noche.

Otro grupo de cláusulas tiene por objeto regular la vestimenta de los judíos, con el fin de evitar que los más poderosos económicamente de ellos pudieran confundirse con miembros del sector más elevado de la sociedad cristiana. Así, además de prohibirse a judíos y moros vestir paños de precio superior a 30 maravedíes la vara, se obliga a los judíos a cubrirse la cabeza con capirotes con chías ${ }^{15}$ largas y a llevar sobre la ropa tabardos ${ }^{16}$ con aletas, así como la rodela bermeja sobre el hombro derecho. Las mujeres judías, por su parte, habrían de llevar mantos largos, sin cendal ${ }^{17}$ ni peña ${ }^{18}$, y las cabezas cubiertas con mantos doblados.

Con la misma finalidad de que los judíos fueran fácilmente identificados, la disposición decimoctava prohíbe a los varones cortarse la barba y los cabellos, de forma que habrían de llevarlos largos, como acostumbraban antiguamente.

En una línea parecida, la disposición duodécima prohíbe adjudicar a judíos y moros el título honorífico de «don».

Otros artículos prohíben a judíos y moros el ejercicio de numerosas actividades profesionales. La disposición segunda les prohíbe ejercer como especieros y boticarios, y como médicos y cirujanos, así como vender productos de comer a cristianos y tener tiendas con botica o mesas en público para vender cosas de comer, bajo pena de 2.000 maravedíes. La disposición quinta les prohíbe ejercer como arrendadores, procuradores, almojarifes o mayordomos del rey o de señores, como corredores y cambiadores, y portar armas, todo ello bajo pena de 2.000 maravedíes. La disposición vigésima les prohíbe ejercer como albéitares, herradores, carpinteros, jubeteros, sastres, tundidores, calceteros, carniceros, pellejeros o traperos para cristianos, así como vender a éstos zapatos y ropas. Y la disposición vigésimo primera les prohíbe desempeñar el oficio de recuero y transportar productos alimenticios para su venta a cristianos, citando en concreto aceite, miel y arroz.

A través de otro grupo de disposiciones se trata de cercenar la autonomía de las aljamas de judíos y moros, prohibiéndoles disponer de jueces propios para juzgar sus pleitos civiles y criminales que, en adelante, habrían de ser librados por los al-

15 La chía es la parte de una vestidura llamada beca, hecha de paño fino, con una rosca que se ponía en la cabeza, de la cual bajaban dos faldones que caía uno hasta el cuello y el otro, que propiamente era la chía, hasta la mitad de la espalda.

16 Prenda de abrigo ancha y larga, de buriel o paño tosco, con las mangas anchas y abiertas.

17 Tela de seda o lino muy delgada y transparente.

18 Piel para forro o adorno. 
caldes de las ciudades, villas o lugares en las que moraran, quienes aplicarían las costumbres y ordenanzas propias de los judíos y moros (disposición séptima). Asimismo se prohíbe a las aljamas ordenar pechos o tributos internos sin el consentimiento previo del rey y de los regidores del reino (disposiciones octava y novena).

El Ordenamiento trata de limitar la capacidad de judíos y moros de desplazarse libremente por el reino, a cuyo fin se les prohíbe trasladarse a vivir a otro lugar distinto del que moran (disposición decimosexta), se prohíbe a los señores acoger en su villa o lugar a judíos y moros que se trasladaban a vivir a otro lugar (disposición decimoséptima), y se establece que los judíos y moros que fueran prendidos tratando de dejar el reino y señoríos reales perdieran todos los bienes que llevaran con ellos y quedaran para siempre como cautivos del rey (disposición vigesimotercera).

Pese a la dureza extrema de las disposiciones contenidas en el Ordenamiento, la disposición tercera deja sentado el principio de que la conversión de judíos y moros al cristianismo debería ser voluntaria, de forma que no podrían ser forzados a ello ni incluso por padres o hermanos ${ }^{19}$.

Por último, la disposición vigesimosegunda autoriza a cualquier persona a denunciar el incumplimiento de cualquiera de las leyes contenidas en el Ordenamiento, concediéndole la tercera parte de la cantidad señalada en la pena, y la disposición vigesimocuarta concluye estableciendo que las penas señaladas en cada una de las leyes que integran el Ordenamiento no podrían ser modificadas por ninguna autoridad, aunque fueran los señores de la localidad y tuvieran el mero y mixto imperio.

Las diversas disposiciones que se contienen en el Ordenamiento de 1412 no eran una novedad en el reino de Castilla, de forma que la mayor parte de ellas habían sido ya aprobadas en sucesivas reuniones de Cortes, desde mediados del siglo XIII y a lo largo de todo el siglo XIV, a solicitud de los representantes de las ciudades y villas del reino. Y las que podrían considerarse novedosas, como la que obligaba al apartamiento de judíos y moros en barrios aislados, ya había conocido algún intento de aplicación práctica, como tendremos ocasión de comprobar. Lo que resulta original del Ordenamiento de 1412 es que constituye un completísimo corpus legal en el que se recogen las disposiciones de carácter segregador para con las comunidades judía y mudéjar que habían ido recogiéndose, con mayor o menor efectividad práctica, en diversos cuadernos de Cortes, y que, en muchas ocasiones, tenían su origen en cánones de concilios y sínodos eclesiásticos. La finalidad perseguida era, probablemente, producir un sentimiento de desánimo entre los judíos, haciéndoles perder las esperanzas de que, tras las persecuciones de 1391, las aguas regresarían a su cauce, y de este modo moverles a la conversión al cristianismo. Si las leyes se aplicaran de forma estricta, los judíos más poderosos e influ-

${ }^{19}$ Esta disposición es acorde con la actitud oficial de la Iglesia para con los judíos, desde San Agustín y a lo largo de buena parte de la Edad Media. Su primera expresión se encuentra en los escritos del papa San Gregorio I Magno (590-604), y se plasma asimismo en la Constitutio pro iudaeis del papa Inocencio III, promulgada en el año 1199, y en las Decretales de Gregorio IX, compiladas por San Raimundo de Peñafort en 1234. 
yentes se empobrecerían y los más débiles económicamente carecerían de recursos para sobrevivir, lo que provocaría la crisis económica y moral de la comunidad. Y todo hace pensar que, efectivamente, tras la promulgación de la Pragmática las campañas de predicación de fray Vicente Ferrer tuvieron bastante éxito en varias de las localidades que visitó, logrando un número importante de conversiones.

El Ordenamiento de Valladolid de 1412 no fue llevado a la práctica de forma estricta y con carácter general en todo el reino de Castilla; como señala Fernando Suárez, el rigor extremo de las leyes que lo integran y su excesiva amplitud fueron factores que dificultaron su aplicación ${ }^{20}$. Aunque, muy probablemente, lo que más incidió en su escasa aplicación fue la falta de convencimiento de las máximas autoridades del reino en su bondad. Así, no deja de ser significativo que con fecha de 25 de enero de 1412, unos días después de haber sido promulgado el Ordenamiento, el regente Fernando de Trastámara se dirigía a las autoridades de la ciudad de Toledo instándoles a que no lo pusieran en práctica hasta que estudiara sus leyes ${ }^{21}$. Del mismo modo, poco tiempo después de haber sido elegido rey de Aragón en el Compromiso de Caspe, el 24 de junio de 1412 Fernando hacía publicar en Cifuentes una versión modificada, y algo menos rigurosa, de la Pragmática de doña Catalina para la zona de Castilla que estaba bajo su gobierno. El grado de aplicación del Ordenamiento de 1412 varió de unas a otras localidades, en función del mayor o menor empeño que pusieron las autoridades locales en su cumplimiento, lo que permite observar a lo largo del siglo XV una notable disparidad en el tratamiento de la cuestión judía entre unas y otras localidades castellanas. Lo más peligroso de la nueva situación es que desde este momento los concejos castellanos disponían de un instrumento legal con el que podían hacer realmente imposible la vida de los judíos.

Al no existir un interés especial por llevar a la práctica la orden de apartamiento de judíos y moros en barrios aislados, unos y otros continuaron residiendo en las mismas calles y viviendas donde hasta entonces venían haciéndolo. Pese a todo, constan documentalmente algunos intentos concejiles de apartamiento de los judíos, en algún caso antes incluso de la promulgación del Ordenamiento de 1412, como sucedió en la localidad soriana de Ágreda en 1406. El proyecto de apartamiento de los judíos de Ágreda se gestó en medios eclesiásticos, y parece que en un primer momento contó con el beneplácito del regente Fernando de Trastámara, quien ordenó a los judíos que se recluyeran en el sector urbano que les había sido señalado por el arcipreste de la villa. Los judíos recurrieron esta disposición ante la justicia regia, alegando que gozaban de un privilegio del año 1402, e incluso de otro anterior, de tiempos del rey Juan I, en el que se les autorizaba a residir en cualquiera de los barrios de la localidad. La disputa, muy larga, dio lugar a réplicas y contrarréplicas, a través de las cuales queda de manifiesto la radical oposición de los judíos a recluirse en un

20 Fernando SUÁREZ BILBAO, El fuero judiego en la España Cristiana. Las fuentes jurídicas. Siglos $V-X V$, pág. 112.

${ }^{21}$ Archivo Municipal de Murcia, cartulario de los años 1391-1412, fol. 136ro․ Juan TORRES FONTES, «Moros, judíos y conversos en la regencia de Don Fernando de Antequera», pág. 69. 
barrio apartado y, lo que es mucho más significativo, el decidido apoyo que la aljama encontró en las autoridades concejiles, quienes intervinieron en el pleito informando al regente castellano de que hasta entonces nunca los judíos de Ágreda habían tenido judería apartada, como en apoyo de su pretensión afirmaban el obispo de Tarazona y el arcipreste de Ágreda. Es de gran interés comprobar la toma de posición de las autoridades concejiles, quienes, quizá por una pugna de jurisdicciones con el obispo, tomaron partido a favor de los judíos, lo que, con toda probabilidad, influiría de forma decisiva en la sentencia del regente castellano, quien ordenó dejar en suspenso el proyecto de apartamiento de los judíos de Ágreda ${ }^{22}$.

Por otra parte, no cabe ninguna duda de que si el Ordenamiento se hubiera aplicado de forma estricta ello habría supuesto el fin irremediable del judaísmo castellano, ya que cercenaba a los judíos todas las posibilidades de actuación socio-profesional, no dejándoles otra vía abierta más que el préstamo con interés, que, al margen de que sólo podría ser desempeñado por aquellos individuos que disfrutaban de una posición socio-económica más elevada, era precisamente la actividad que mayores antipatías populares generaba a los judíos. Este argumento es una razón más que invita a sostener la falta de aplicación efectiva y general del Ordenamiento de 1412.

No obstante, la presión legislativa antijudía no quedó limitada al reino de Castilla, sino que tuvo también su manifestación en la Corona de Aragón. Elegido en 1412 rey de Aragón el regente castellano Fernando de Trastámara, probablemente hubo de ceder a la presión de Benedicto XIII y de fray Vicente Ferrer, que tan importante papel desempeñaron en apoyo de su candidatura en el Compromiso de Caspe $^{23}$, y el 20 de marzo de 1413 acordaba la puesta en vigor en la Corona de Aragón de unas disposiciones similares a las contenidas en el Ordenamiento de Valladolid de 1412. Parece razonable sospechar la presión ejercida por el Papa Luna y por fray Vicente, si tenemos en cuenta que fueron los instigadores del Ordenamiento de Valladolid de 1412 y el poco empeño que había puesto Fernando de Trastámara en su aplicación en Castilla ${ }^{24}$. En este contexto, entre los meses de enero de 1413 y noviembre de 1414, y a propuesta de Benedicto XIII, se celebró la llamada Disputa o Controversia de Tortosa, que reunió en esta ciudad catalana a algunos afamados teólogos cristianos y a los más reputados rabinos de la Corona de Aragón, con el fin de debatir acerca de si Jesucristo era o no el

\footnotetext{
22 Archivo Municipal de Ágreda, A. 5 C, 16, L.3ํ, n. 1. Francisco CANTERA BURGOS, «Juderías medievales de la provincia de Soria», en Homenaje a Fray Justo Pérez de Urbel, OSB, Silos, 1976, vol. I, págs. 445-482 (véase, en concreto, pág. 451).

${ }^{23}$ Es probable también que en la toma de postura del nuevo rey de Aragón influyera el deseo de situar a sus hijos en puestos políticos clave en el reino de Castilla, entre ellos los maestrazgos de las Órdenes Militares, para lo que sería de gran ayuda un buen entendimiento con el papa Benedicto XIII.

24 Las leyes aprobadas para la Corona de Aragón incorporaban algunas novedades con relación al Ordenamiento de Valladolid de 1412, como la prohibición para los judíos de disponer de más de una sinagoga en cada localidad y de guardar ejemplares del Talmud, y la obligación de oir sermones de predicadores cristianos tres veces al año, el segundo domingo de Adviento, el lunes de Pascua y un tercer día que sería fijado por la autoridad local. Estas disposiciones serán recogidas algún tiempo después en la bula «Etsi Doctores Gentium», otorgada por Benedicto XIII el 22 de mayo de 1415, lo que deja a las claras la influencia ejercida por el Papa sobre el nuevo monarca aragonés.
} 
Mesías anunciado en el Antiguo Testamento; aunque no parece que hubiera muchos resultados concretos, sí se produjeron algunas conversiones al cristianismo en las fechas inmediatamente posteriores a la Disputa ${ }^{25}$. Tras la conferencia de Tortosa debió existir la esperanza y un firme propósito de terminar con el judaísmo en los reinos hispánicos, de lo que es una buena prueba la legislación emanada de la cancillería de Benedicto XIII. Así, el 22 de mayo de 1415, Benedicto XIII otorgaba la bula «Etsi Doctoris Gentium», en la que se renovaba la antigua disposición del IV Concilio de Letrán de 1215 que obligaba a las autoridades públicas cristianas a llevar a cabo una estricta separación de judíos y moros respecto de los cristianos, se disponía que los judíos habrían de entregar todos los libros que poseían escritos en hebreo, en particular el Talmud, y se ordenaba que todos los judíos varones mayores de doce años habrían de acudir de forma obligatoria tres veces al año a las predicaciones públicas convocadas por frailes y sacerdotes ${ }^{26}$. En definitiva, la bula «Etsi Doctoris Gentium» pretendía hacer extensiva a toda la Cristiandad algunas de las disposiciones contenidas en el Ordenamiento de Valladolid de 1412.

\section{LA NUEVA DIRECCIÓN DE LA POLÍTICA CASTELLANA EN RELACIÓN CON LOS JUDÍOS: LA PRAGMÁTICA DE ARÉVALO DE 1443}

Sin embargo, pese a los negros augurios con los que se iniciaba para los judíos de Castilla el reinado de Juan II, la situación iba a cambiar pronto de forma significativa. En noviembre de 1414 se iniciaba el Concilio de Constanza, en el que el 26 de julio de 1417 se acordaría la deposición del Papa Luna, auténtico instigador de la política antijudía; ya desde 1416 los monarcas hispanos se habían sustraído a la obediencia a Benedicto XIII, y en este mismo año moría Fernando I de Aragón. En este nuevo contexto, el 21 de septiembre (12 de las kalendas de octubre) de 1421, el papa Martín V promulgó una bula por la que acordaba la abolición de las duras disposiciones contenidas en la bula «Etsi Doctoris Gentium» de Benedicto XIII. Esta bula, que Javier Castaño considera una variante de la bula «Sicut Judaeis» promulgada por Calixto II en el año $1120^{27}$, reconoce el derecho de los judíos de Castilla a vivir entre cristianos, con el fin de que con el ejemplo y la amonestación de éstos pudieran llegar a conocer a Cristo, y les autoriza a realizar todo tipo de actividades profesionales, incluidas la medicina, la correduría y la procuraduría con cristianos, así como a actuar como arrendadores y recaudadores de rentas, a tener compañía de bienes con cristianos y a tener tiendas y obradores y a trabajar entre los cristianos. Esta bula fue otorgada a petición de procuradores de la comunidad judía castellana desplazados a Roma, que contaron, con toda probabilidad, con la mediación de la corte castellana, con el fin de que fueran derogadas las duras disposiciones contenidas en la bula «Etsi

\footnotetext{
${ }^{25}$ Acerca de la Controversia de Tortosa se dispone del completo estudio de Antonio PACIOS LÓPEZ, La disputa de Tortosa. Madrid. CSIC, 1957, 2 vols.

26 Joseph PEREZ, Los judíos en España. Madrid. Marcial Pons, 2005, págs.132-133.

27 Javier CASTAÑO GONZÁLEZ, «Las aljamas judías de Castilla a mediados del siglo XV: la Carta Real de 1450", en En la España Medieval, no 18 (1995), págs. 181-203 (en concreto, págs. 185-186).
} 
Doctoris Gentium» de Benedicto XIII28. Otra bula de Martín V, emitida también el 21 de septiembre de 1421, prohíbe los bautismos forzados de judíos; pero esta bula no mantuvo su vigencia durante mucho tiempo, debido a la presión que ejercieron los franciscanos observantes, quienes lograron su derogación por el Papa en $1423^{29}$. La promulgación de estas bulas de Martín $\mathrm{V}$ tenía lugar en un momento en el que el rey Juan II había recobrado la libertad después de los meses de cautiverio al que le tuvo sometido el infante don Enrique tras el golpe de Tordesillas de julio de 1420, habiéndose afianzado en el poder nuevamente Álvaro de Luna. No es ilógico, por tanto, presuponer una intervención de la corte castellana ante el Papa en apoyo de las pretensiones de los procuradores de las aljamas castellanas.

Entre tanto, en junio de 1418 moría la reina madre Catalina de Lancaster, y en marzo de 1419 Juan II alcanzaba la mayoría de edad, momento a partir del que se inicia su reinado efectivo, un reinado largo y convulso marcado por el enfrentamiento permanente entre el valido Álvaro de Luna y los infantes de Aragón. Casi inmediatamente llegaba a la corte Álvaro de Luna, quien se rodeó de personajes con una alta preparación para la actividad pública, entre los que sobresalen algunos judíos y judeoconversos, y de manera muy especial un judío de origen soriano, Abraham Bienveniste, quien se había incorporado al séquito de Álvaro de Luna en 1420, tras haber estado al servicio de Juan Hurtado de Mendoza. Abraham Bienveniste era un experto economista y una de las figuras más destacadas del judaísmo castellano del siglo XV; junto con Álvaro de Luna, Juan Hurtado de Mendoza y Fernán Alonso de Robles, se encargó de reorganizar el sistema de recaudación de impuestos, que nuevamente fue puesto en manos, en buena medida, de arrendadores judíos, y en algunos documentos de los años treinta aparece citado como recaudador mayor. Desde su privilegiada posición en la corte actuó en favor de sus correligionarios, consiguiendo que paulatinamente fuesen eliminados los obstáculos que limitaban la actuación pública de los judíos. Su decisiva intervención en la organización y administración económica de la campaña emprendida en 1429 contra el rey Alfonso $V$ de Aragón y sus hermanos, que llevó nuevamente al poder a Álvaro de Luna, sería recompensada largamente por el valido. El 11 de septiembre de 1431 Abraham Bienveniste recibió el nombramiento de Rab Mayor de la Corte, con carácter vitalicio ${ }^{30}$, otorgándole la misma autoridad y prerrogativas que habían sido concedidas

${ }^{28}$ La bula de Martín V de 1421 se contiene en la Carta Real de 1450, y ha sido transcrita por Javier CASTAÑO GONZÁLEZ, «Las aljamas judías de Castilla a mediados del siglo XV: la Carta Real de 1450», pág. 195-198, y por Fernando SUÁREZ BILBAO, El fuero judiego en la España Cristiana. Las fuentes jurídicas. Siglos $V-X V$, págs. 435-437.

${ }_{29}$ Para profundizar en el conocimiento de la influencia que las órdenes mendicantes tuvieron en el desarrollo del antijudaísmo, es interesante el estudio de J. COHEN, The Friars and the Jews. The evolution of Medieval Antijudaism. London, 1982.

${ }^{30}$ La carta de nombramiento de Abraham Bienveniste como Rab Mayor está inserta en otra anterior, cuya fecha no aparece suficientemente clara. Macarena Crespo Álvarez, en su estudio sobre el cargo de Rab Mayor de la Corte, considera que pudiera ser de 26 de noviembre de 1421, lo que adelantaría en diez años la fecha de su nombramiento (véase Macarena CRESPO ÁLVAREZ, «El cargo de Rab Mayor de la corte según un documento de Juan II fechado en 1450", en Edad Media. Revista de Historia, 4 (2001), págs. 157-198, en concreto págs. 168-169). 
por Juan I y Enrique III a Me'ir Alguadex ${ }^{31}$. La recuperación de esta magistratura que, al parecer, había quedado sin continuidad tras la muerte de Me'ir Alguadex (al menos, no se conoce el nombre de ningún Rab Mayor entre Me'ir Alguadex y Abraham Bienveniste), es una señal evidente del deseo del rey Juan Il y de Álvaro de Luna de retornar a la tradicional política de protección a los súbditos judíos. Desde su nuevo cargo, Abraham Bienveniste se esforzó por recuperar la antigua estructura orgánica de la comunidad judía castellana, que había desaparecido prácticamente tras los desastres de 1391.

Del mismo modo, las disposiciones contenidas en el Ordenamiento de 1412 cayeron muy pronto en el olvido, ante la decidida voluntad del monarca y su valido de no exigir su cumplimiento. Del mismo modo, llama poderosamente la atención las escasísimas referencias a los judíos en los cuadernos de Cortes de tiempos de Juan II de Castilla, de forma que en las cerca de 30 reuniones de Cortes celebradas a lo largo de su reinado, tan sólo en las de Burgos de 1430 y en las de Madrigal de 1438 se hace referencia explícita a los judíos. Y no deja de ser también significativo que cuando en las Cortes de Madrid de 1435 y en las de Toledo de 1436 se trata acerca de los arrendadores de rentas no se haga mención expresa a los judíos.

En las Cortes de Burgos de 1430 se solicitó al rey que se hicieran guardar las ordenanzas de Enrique III que prohibían a judíos y moros ejercer los oficios de arrendadores y recaudadores, así como otros cualesquier que comportaran el ejercicio de algún tipo de autoridad sobre cristianos. El rey contestó con evasivas, afirmando que mandaría ver las ordenanzas y bulas apostólicas que los judíos tenían sobre ello, y que actuaría en consecuencia ${ }^{32}$. En las Cortes de Madrigal de 1438 se solicitó el castigo para quienes practicaran la usura, haciéndose una excepción en el caso de los judíos, a los que se autoriza a obtener un interés de hasta el $25 \%$. Asimismo se solicitó al rey que se hicieran cumplir las ordenanzas que obligaban a judíos y moros a llevar las señales identificativas externas, porque, según se decía, las incumplían reiteradamente. En ambos casos, el rey ordenó que se cumplieran las disposiciones ordenadas sobre ello ${ }^{33}$.

${ }^{31}$ Me'ir Alguadex es una destacada figura del judaísmo castellano de fines del siglo XIV y comienzos del XV, que alcanzó el cargo de Rab Mayor de la Corte y que ejerció como médico en la corte castellana desde tiempos de Juan I; asimismo tuvo a su cargo, muy probablemente, tareas financieras de la corona. Como recoge fray Alonso de Espina en su Fortalitium Fidei (Libro tercero, Consideración décima, décimo milagro, ff. 223ro-233º), obra aparecida en torno al año 1460, en 1410 Me'ir Alguadex fue acusado, junto a otros judíos, de participar en la profanación de una Hostia consagrada en Segovia. En el proceso promovido por el obispo Juan de Tordesillas, sometido a tormento, Me'ir Alguadex confesó haber intervenido en dicha profanación y, asimismo, haber causado la muerte del rey Enrique III suministrándole un veneno mortal. Sentenciado a pena de muerte, fue ahorcado, arrastrado por la ciudad y descuartizado (Disponemos de una excelente edición del libro tercero del Fortalitium Fidei, de la que es autora Alisa MEYUHAS GINIO, Fontes Iudaeorum Regni Castellae. VIII. De bello iudaeorum. Fray Alonso de Espina y su Fortalitium Fidei. Salamanca, 1998).

${ }_{32}$ Cortes de los antiguos reinos de Castilla y León. Madrid, 1861, vol. III, pág. 88. Fernando SUÁREZ BILBAO, El fuero judiego en la España Cristiana. Las fuentes jurídicas. Siglos V-XV, pág. 394.

${ }_{33}$ Cortes de los antiguos reinos de Castilla y León. Madrid, 1861, vol. III, pág. 319, 320 y 365 . Fernando SUÁREZ BILBAO, El fuero judiego en la España Cristiana. Las fuentes jurídicas. Siglos V-XV, págs. 404-405. 
Cabe preguntarse a qué puede deberse este clamoroso silencio de las Cortes castellanas acerca de los judíos, cuando a lo largo de la segunda mitad del siglo XIII y de todo el siglo XIV fueron constantes las referencias a ellos en las reuniones de Cortes. Las explicaciones pueden ser diversas. En primer lugar, cabe sospechar que tras las persecuciones de 1391 y las predicaciones de fray Vicente Ferrer el número de los judíos y su peso cualitativo en el conjunto de la sociedad castellana había disminuido tan considerablemente que habrían dejado de constituir un foco de atención para los procuradores de las ciudades y villas. En este sentido, es significativo que a lo largo del siglo XV las acciones violentas en el reino de Castilla no fueron dirigidas contra los judíos sino contra los judeoconversos y, con frecuencia, estuvieron teñidas de un indiscutible cariz de protesta social. En su condición de cristianos, los judeoconversos no tenían ninguna limitación de índole religiosa, jurídica o económico-social, lo que generaba profundas reticencias entre los cristianos viejos, que comenzaron a acusar a los judeoconversos de haberse convertido al cristianismo de forma meramente interesada y ficticia, y de seguir practicando en secreto la religión judía. Es posible, por tanto, que la atención se desviara de los judíos hacia los judeoconversos.

Por otra parte, es posible también que los procuradores de las ciudades y villas en Cortes consideraran que el Ordenamiento de Valladolid de 1412, que formalmente no sería derogado hasta la Pragmática de Arévalo de 6 de abril de 1443, estaba en vigor y que, por tanto, no era necesario insistir en la aprobación de disposiciones concretas relativas a los judíos, ya que el Ordenamiento contenía todo aquello que había sido reclamado en las Cortes a lo largo de los siglos XIII y XIV. En definitiva, si lo consideraban conveniente, los concejos podrían poner en práctica las disposiciones recogidas en el Ordenamiento de 1412.

En el año 1428 el papa Martín V otorgaba una nueva bula, también abiertamente favorable a los intereses de los judíos quienes, sin duda, estaban dando pasos decididos en un proceso de reorganización y centralización, que contaba con el apoyo o, quizá mejor dicho, que era impulsado por el Condestable Álvaro de Luna. Esta bula respondía a la queja de los procuradores de los judíos de España y Nápoles ante el Papa a causa de los agravios que recibían por parte de cristianos y de las predicaciones que animaban a éstos a apartarse de los judíos. Esta bula, dada por Martín V en Roma el 13 de febrero (idus de febrero) de 1428, comienza afirmando que, pese a su «dureza e ceguedad» en reconocer a Jesucristo como el Mesías ${ }^{34}$,

${ }^{34}$ El rechazo de Jesús como el Mesías anunciado en el Antiguo Testamento motivó la acusación a los judíos de pertinacia y contumacia en la fe, de forma que diversas obras de apologética antijudía hacen referencia a la «ceguera intelectual» de los judíos, que les impediría reconocer en Jesús al Mesías, pese a que fue a ellos a quienes primero se manifestó. La obstinación judaica en no reconocer a Cristo como el Mesías se representa, frecuentemente, mediante una figura de mujer, la Sinagoga, con los ojos vendados. Entre las obras de apologética que resaltan la «ceguera de los judíos» pueden ser citadas, entre otras, los tratados Contra caecitatem iudaeorum de fray Bernardo de Oliver, y El libro de la sabiduría de Dios de Alfonso de Zamora, que cuentan con dos excelentes ediciones a cargo de Francisco CANTERA BURGOS, El tratado «Contra caecitatem iudaeorum» de fray Bernardo de Oliver. Edición crítica y bibliografía, Madrid, 1965, y de Federico PÉREZ CASTRO, El manuscrito apologético de Alonso de Zamora, Respons., traducción y estudio de Séfer Hokmat Elohim por..., Madrid, CSIC, 1950. 
los judíos eran tolerados por la Iglesia en diversos lugares con la esperanza de que, atraídos por la mansedumbre y la clemencia de los cristianos, llegaran a reconocer sus errores y a descubrir a Cristo. Seguidamente se afirma que los procuradores de los judíos de España y Nápoles se habían quejado ante el Papa de que algunos predicadores mendicantes y de otras órdenes insistían en sus sermones a los cristianos que, bajo pena de excomunión, se apartaran de los judíos y no participaran con ellos en trabajos, y que otros cristianos los injuriaban y maltrataban, dando lugar con ello a que los judíos porfiaran en sus creencias. Atendiendo a esta súplica, el Papa prohibía a los maestros y predicadores que predicaran contra los judíos sin autorización expresa de los ordinarios, a los inquisidores que procedieran contra los judíos salvo en casos de manifiesta herejía, y a los fieles cristianos que hicieran injuria y cualquier tipo de daño en los bienes de los judíos. Asimismo prohibía que se obligara a los judíos a acudir a los oficios divinos de los cristianos o a convertirse a la fe cristiana, y que se incitara a cualquier judío menor de 12 años, o que no fuera capaz de discernir, a recibir el bautismo sin el consentimiento de sus padres. Del mismo modo, se prohibía que se obligara a los judíos a trabajar en sábado o en día de descanso de la religión judía, y que se les impidiera el libre cumplimiento de sus ritos y festividades religiosas. El Papa manifestaba su deseo de que los judíos fueran tratados con mansedumbre y humanidad, y les autorizaba a contratar, comprar y vender con cristianos, así como a tener estudios de la Ley judía, con tal de que no leyeran libros latinos o judíos contrarios al Antiguo Testamento, a los Profetas y a la fe católica. Asimismo se reconocía a los judíos el derecho a reparar y reformar sus sinagogas y escuelas, a tener cementerios propios, a gozar de todos los privilegios otorgados tanto por la sede apostólica como por los reyes y señores, y a tener sus jueces propios para asuntos civiles, pleitos y controversias que entre ellos se plantearan.

Después de que en 1427 Álvaro de Luna hubiera sido expulsado del poder por la acción conjunta de Juan de Navarra y del infante Enrique, en 1429 logró recuperarlo, gracias al apoyo de numerosos nobles a los que ofreció una participación en el gobierno del reino y en los bienes de los infantes; las treguas de Majano de 1430 sellaron la paz con Alfonso V de Aragón, y supusieron la expulsión de Castilla de los infantes de Aragón. El triunfo de Álvaro de Luna fue seguido de una recompensa generosa en bienes raíces, cargos y títulos a sus aliados; en este contexto se produce el nombramiento de Abraham Bienveniste como Rab Mayor de los judíos. Las favorables condiciones en las que en este momento se desarrollaba la vida de las comunidades judías castellanas tiene su más evidente expresión en la aprobación de las Taqqanot de Valladolid de $1432^{35}$. En este año, bajo la presidencia de Abraham Bienveniste, Rab Mayor de los judíos de Castilla, y contando con el beneplácito de Álvaro de Luna, se reunieron en Valladolid representantes de

35 Una excelente edición de estas Taqqanot es la de Yolanda MORENO KOCH, Fontes ludaeorum Regni Castellae. V. De iure hispano-hebraico. Las Taqqanot de Valladolid de 1432. Un estatuto comunal renovador. Salamanca. Universidad Pontificia de Salamanca-Universidad de Granada, 1987. 
las más importantes aljamas castellanas y algunos destacados cortesanos judíos, con la finalidad de redactar unos estatutos (taqqanot) que sirvieran como norma de gobierno para todas las comunidades hebreas del reino de Castilla. Estas Taqqanot cimentan la unión entre los judíos en la religión y se esfuerzan por restablecer la independencia judicial de sus comunidades, de tal modo que se prohíbe a los judíos acudir a tribunales de justicia cristianos para dirimir pleitos internos; asimismo se ordena a las aljamas que procedan a la elección de jueces, que habrían de renovarse todos los años. Una de las cuestiones más complejas que fueron tratadas es la que se refiere al reparto de las tributaciones, debido a los enfrentamientos internos que con frecuencia se daban en las comunidades; a fin de evitar las habituales disputas, se arbitraron medidas para que una parte de las imposiciones se pagara por cabezas, según el deseo de los sectores más poderosos de las comunidades, y otra parte según la capacidad económica de los individuos, como solicitaban los sectores sociales más desfavorecidos. Por otra parte, se hacía una recomendación al abandono del lujo, no sólo con el propósito de que los judíos recordaran que estaban en el exilio, sino también con objeto de no despertar las envidias de los cristianos. La Asamblea de Valladolid reforzó la figura del Rab Mayor como autoridad suprema de los judíos de Castilla, lo que contribuyó al fortalecimiento de los lazos de cohesión entre las aljamas.

Las Taqqanot de Valladolid eran el resultado de un movimiento integrador surgido en el seno del judaísmo castellano como reacción frente a las dificilísimas circunstancias en que se vieron inmersas las comunidades judías tras las persecuciones de 1391 y la promulgación de los Ordenamientos de 1405 y 1412. Los judíos comprendieron que el medio más eficaz, probablemente el único, para hacer frente a la terrible amenaza que les acechaba consistía en el reforzamiento de los lazos de cohesión internos y en el retorno a las tradiciones religiosas, esforzándose los rabinos y las autoridades comunitarias en predicar la austeridad en las costumbres y en los modos de vida. Por lo tanto, se trataba de cerrar filas frente al hostigamiento externo, reforzando los vínculos religiosos. Las Taqqanot constituyeron unos cimientos firmes en el proceso de consolidación del judaísmo castellano, de forma que durante seis decenios, entre 1432 y 1492, la comunidad judía castellana logró reconstruir su antigua situación sobre unas bases sociales y religiosas renovadas, lo que le permitió recuperar buena parte de su prosperidad económica. $Y$ en este proceso de reconstrucción del judaísmo castellano fue ciertamente importante el papel desempeñado por Álvaro de Luna, artífice del restablecimiento de la autoridad monárquica, y principal valedor de los judíos frente a la Liga nobiliaria, que desde el primer momento trató de rentabilizar en su favor la tradicional antipatía del pueblo hacia ellos. Por el contrario, el restablecimiento del judaísmo castellano después de 1432 es probable que levantara algunas suspicacias en medios eclesiásticos, por el temor a que algunos judeoconversos pudieran pretender un retorno a sus antiguas creencias.

Por los mismos años, los judíos castellanos seguían solicitando el amparo de la curia pontificia frente a las injurias que recibían por parte de cristianos y para que 
se les autorizara ejercer libremente su religión. El 24 de diciembre (kalendas nonas de enero) de 1436, en Bolonia, el papa Eugenio IV otorgaba una bula que amparaba a los judíos en el cumplimiento de sus ritos y costumbres ${ }^{36}$. En la bula se afirma que los judíos no deben hacer en sus sinagogas otra cosa que lo que el derecho les permite, pero que no deben sufrir agravios ni perjuicios, y que a la Iglesia conviene dar ayuda a los judíos contra quienes los persiguen y maltratan, especialmente porque son reservados en testimonio de la santa fe. Por ello, prohíbe a los inquisidores, a los oficiales y jueces de las ciudades y lugares de Castilla donde moraban judíos, y a todos los fieles cristianos, que en adelante maltrataran a los judíos, les molestaran en la celebración de sus fiestas, les exigieran otros tributos distintos que los que solían pagar, les forzaran a asistir a sermones de cristianos, les obligaran a recibir el bautismo o a trabajar en sábado, o les impidieran el cumplimiento de sus ritos y costumbres. Asimismo se ordena a los oficiales y justicias que no vejen ni maltraten a los judíos, que en las causas espirituales remitieran a los judíos a los ordinarios de los lugares, y en las causas civiles a quien de derecho correspondiera, y que trataran a los judíos mansa y humanamente. Del mismo modo, se autoriza a los judíos a conversar y contratar con cristianos, a los cristianos a cocer el pan de los judíos y a encenderles el fuego, y a los judíos a desempeñar los oficios de contador, recaudador, tesorero y cambiador de cristianos, a tener boticas y tiendas de mercaderías, y a leer y estudiar en sus sinagogas libros de su religión y ciencia. Se concede también a las mujeres judías cuyo marido se hubiera convertido al cristianismo y quisieran permanecer en la religión judía que, si no querían seguir conviviendo con su marido, éste les entregara la parte de la dote que fuera necesaria para su mantenimiento; y que si el marido se casara con una mujer cristiana, que entregara a la mujer judía la dote entera. Y los judíos que se convirtieran al cristianismo habrían de contentarse con la parte que les correspondiera en la sucesión, o por testamento si no se hubieran convertido. La bula concluye autorizando a los judíos el disfrute de todos los privilegios que se les habían concedido tanto por la sede apostólica como por los reyes, y ordenando a todos los ordinarios de las ciudades y lugares que requirieran a los cristianos que no molestaran ni maltrataran a los judíos, bajo pena de excomunión.

Sin embargo, y quizá como resultado de la situación cambiante que conocía la política castellana, el 9 de junio de 1441 el propio papa Eugenio IV daba una nueva bula, denominada «Ad Futuram Rei Memoriam», por la que se revocaba la bula de 24 de diciembre de 1436. Alegando que los judíos de Castilla habían abusado de las concesiones realizadas, se establece que, en adelante, éstas no tendrían efectividad si fueran contrarias al Derecho común.

Unos años después, y en medio de los enfrentamientos que se vivían entre la levantisca nobleza, encabezada por los infantes de Aragón, y el valido Álvaro de

${ }^{36}$ La bula de Eugenio IV de 1436 se contiene en la Carta Real de 1450, y ha sido transcrita por Javier CASTAÑO GONZÁLEZ, «Las aljamas judías de Castilla a mediados del siglo XV: la Carta Real de 1450», págs. 198-200, y Fernando SUÁREZ BILBAO, El fuero judiego en la España Cristiana. Las fuentes jurídicas. Siglos $V$-XV, págs. 437-439. 
Luna, el 6 de abril de 1443 fue promulgada la Pragmática de Arévalo, un texto de una indudable significación política y de honda trascendencia en la evolución del problema judío en tiempos de Juan II de Castilla ${ }^{37}$. La Pragmática fue promulgada por el rey Juan II, sin duda alguna por el empeño de Álvaro de Luna, en un lapso de tiempo en el que éste trataba de restablecer su autoridad después de que la «Sentencia compromisoria» de julio de 1441 hubiera impuesto una nueva junta de gobierno en Castilla, siguiendo los dictados de los infantes de Aragón, y le hubiera obligado al segundo destierro. Pero el triunfo de los infantes había sido efímero, y en el año 1442 Álvaro de Luna lograba que las Cortes, reunidas en Toro, anularan las donaciones hechas a los nobles en los últimos años y que se pusiera freno a las enajenaciones de bienes reales.

La Pragmática de Arévalo tenía como objetivo principal tomar bajo el amparo real a los judíos y mudéjares del reino quienes, según alegaban, eran dañados en sus personas y bienes so pretexto de la bula «Super Gregem Dominicum», promulgada el 8 de agosto de 1442 por el papa Eugenio IV, a instancias de fray Rodrigo de Oña, con el propósito de retornar a las duras disposiciones de la Pragmática de Valladolid de $1412^{38}$. Con toda seguridad, la preparación de esta bula se había hecho durante el lapso de tiempo coincidente con el segundo destierro de Álvaro de Luna, que habría sido aprovechado por Rodrigo de Oña, quizá en connivencia con los infantes de Aragón, para presionar al Pontífice. La bula «Super Gregem Dominicum» regulaba cómo debían vivir los judíos y mudéjares de Castilla entre los cristianos, y fue hecha pública en Toledo en 1443, contando con la aceptación del rey Juan II y del obispo Gutierre Álvarez de Toledo, que había ascendido a la sede episcopal toledana en $1442^{39}$. La bula prohibía a judíos y mudéjares el ejercicio de ciertas actividades profesionales, principalmente la de juez, así como de oficios relacionados con el arrendamiento y recaudación de rentas y tributos o que llevaran aparejada jurisdicción sobre cristianos. Asimismo regulaba estrictamente la convivencia de cristianos con judíos y mudéjares, prohibiendo que los cristianos recibieran medicinas de judíos y mudéjares, que comieran o bebieran juntos, que par-

37 La Pragmática de Arévalo es transcrita por José AMADOR DE LOS RÍOS, Historia social, política y religiosa de los judíos de España y Portugal, vol. III, págs. 583-589, y más recientemente por Fernando SUÁREZ BILBAO, El fuero judiego en la España Cristiana. Las fuentes jurídicas. Siglos V-XV, págs. 430-434.

${ }^{38}$ El franciscano fray Rodrigo de Oña figura en el año 1445 como nuncio pontificio en Castilla, a donde fue enviado como colector por el papa Eugenio IV, junto con otros frailes franciscanos, para percibir el subsidio correspondiente a la expedición proyectada para rescatar la isla de Rodas de los turcos (José Manuel NIETO SORIA, Iglesia y génesis del Estado Moderno en Castilla (1369-1480). Madrid. Editorial Complutense, 1994, pág. 78).

39 Gutierre Álvarez de Toledo era hijo del magnate Hernán Álvarez, señor de Valdecorneja y mariscal de Castilla, y de Leonor de Ayala y Guzmán, sobrina del canciller Pero López de Ayala. La primera dignidad que obtuvo fue la de arcediano de Guadalajara, interviniendo activamente en la vida política castellana desde la regencia de Fernando de Antequera. En su actuación pública se caracterizó siempre por la defensa de posiciones antijudías, defendiendo la prohibición a los judíos del ejercicio de oficios y cargos públicos. En 1422 el papa Martín V lo nombró administrador de la diócesis de Palencia, en 1439 accedió al arzobispado de Sevilla, y en 1442 asumió la sede primada de Toledo. Tomó parte activa en varias expediciones militares frente al reino de Granada. 
ticiparan en convites, que moraran juntos o que acudieran juntos a los baños, así como que judíos y mudéjares tuvieran amas de cría o sirvientes cristianos. En la misma línea, obligaba a judíos y mudéjares a llevar las señales identificativas externas, y les prohibía morar entre cristianos. Sin embargo, les permitía contratar, comprar, vender o permutar cualquier mercancía con cristianos, así como ejercer los oficios de zapatero, curtidor, albardero, sastre, jubetero, fresnero, herrador, pellejero, cambiador, cestero, espartero o caballero, en los que, incluso, podrían contar con cristianos a salario; asimismo se permite a los cristianos guardar sus ganados a judíos y mudéjares y labrar sus heredades, con tal de que no tuvieran compañía en oficio, ni hicieran familiaridad y asidua conversación. También se permite a los cristianos acudir a médicos judíos y mudéjares en tiempo de necesidad, con tal de que las medicinas y las purgas fueran preparadas por cristianos.

Frente a lo establecido en la bula «Super Gregem Dominicum», la Pragmática de Arévalo ordenaba que se amparara a judíos y mudéjares en sus personas y bienes, y que no se consintiera hacerles ningún tipo de daño, ya que «son propios et cosa mía e de mi cámara», por lo que se les ponía bajo el seguro y amparo real. La Pragmática mantenía en vigor disposiciones antiguas que prohibían a los judíos el ejercicio de algunas actividades profesionales, la convivencia con cristianos y el uso simultáneo de los baños, pero, a cambio, se les autorizaba a contratar con cristianos, ya que eso no lo prohibían ni la bula ni las leyes del reino, con tal de que llevaran las señales identificativas y que vivieran en sus barios apartados. Asimismo se ordenaba que fueran tratados con humanidad, como quieren las leyes del reino, ya que ello no va en contra de la bula, y se indica que se va a enviar una súplica al Papa para que sean limitadas las penas pecuniarias establecidas en la bula. Finalmente se ordenaba que, en adelante, no se hicieran ordenanzas ni estatutos contra judíos y mudéjares sin licencia real, y que si algunos se habían hecho que fueran suspendidos hasta que fueran vistos por la justicia regia y se determinara lo que se había de hacer.

En definitiva, la Pragmática de Arévalo devolvió a los judíos y mudéjares de Castilla su plena capacidad de actuación profesional, prohibiendo a concejos y señores redactar ordenanzas o estatutos particulares en contra de sus intereses. Suponía, qué duda cabe, una decidida toma de postura del monarca castellano, que actuaba en este tema siguiendo los dictados de su valido Álvaro de Luna, en defensa de ambas comunidades minoritarias, tratando de poner coto a las disposiciones contenidas en la bula «Super Gregem Dominicum», dada probablemente a instancias de la junta nobiliaria. Pero más allá de su interés particular, lo auténticamente relevante es que la bula «Super Gregem Dominicum» y la Pragmática de Arévalo se insertan en el largo enfrentamiento que tuvo por escenario el reino de Castilla durante el reinado de Juan II entre los defensores de una autoridad regia fuerte y quienes pretendían someter al rey a los dictados de la nobleza. Como en otras ocasiones, los judíos se veían involucrados en las luchas políticas, y tuvieron en los partidarios del reforzamiento de la autoridad monárquica, con el condestable Álvaro de Luna a la cabeza, a sus más firmes valedores; éstos se esforzaron por el 
restablecimiento de las comunidades judías castellanas, a cuyo fin promovieron una legislación claramente proteccionista.

Pero la efectividad práctica de la Pragmática de Arévalo fue muy breve, por cuanto sólo tres meses después de su promulgación, el 9 de julio de 1443, tenía lugar el golpe de estado de Rámaga, en virtud del que el partido aragonés se hacía con el poder, tomando como cautivo al rey Juan Il y provocando la huida de Álvaro de Luna. No obstante, en el programa político del partido de los infantes de Aragón no se hace mención a los judíos, y no hay noticia de que la Pragmática fuera derogada legalmente.

El 16 de junio de 1444 Juan II conseguía liberarse del cautiverio al que le había sometido el infante Juan de Navarra, cabeza del partido aragonés, y el 13 de julio siguiente emitió una cédula dirigida a los concejos de las ciudades y villas más importantes del reino, en la que ordenaba que sus jueces evitasen toda discriminación contra los conversos, que hicieran que se les tratara como si hubieran nacido dentro del cristianismo y que se les permitiera realizar todo tipo de oficios honrados ${ }^{40}$. Es probable que esta cédula sea una señal del poder recobrado por parte del valido Álvaro de Luna, quien siempre se había caracterizado por la defensa de la plenitud de derechos de los cristianos nuevos para el ejercicio de actividades públicas.

\section{LA CARTA REAL DE 1450}

En 1445, tras derrotar a los infantes de Aragón en la batalla de Olmedo, Álvaro de Luna recuperaba plenamente el poder, dando comienzo a un nuevo período de gobierno autocrático, en el que se trata, una vez más, de restaurar la autoridad monárquica, permanentemente amenazada. En los años siguientes a la victoria de Olmedo, Álvaro de Luna promovió una política abiertamente proconversa, que daría lugar a un fuerte sentimiento de oposición en amplios sectores de la población cristiano vieja. Y es en este contexto en el que se produce la revuelta toledana de 1449, con unas connotaciones claramente antijudías y anticonversas ${ }^{41}, y$ cuyo origen se encuentra en la oposición al pago de una tributación impuesta por Álvaro de Luna a la ciudad de Toledo, lo que dio lugar a una violenta reacción contra los recaudadores de impuestos judeoconversos. Inmediatamente, el alcaide toledano Pero Sarmiento promulgó la famosa Sentencia-Estatuto, que decretaba el

40 Benzion NETANYAHU, Los orígenes de la Inquisición en la España del siglo XV, pág. 262.

41 El desarrollo de los acontecimientos toledanos de 1449 es minuciosamente analizado por Eloy BENITO RUANO en sus libros titulados Toledo en el siglo XV. Vida política. Madrid, 1961, y Los orígenes del problema converso. Barcelona, 1976.

Asimismo es muy interesante para el estudio de la rebelión anticonversa de 1449 en Toledo y, en particular, de la controversia intelectual que se entabló entre quienes defendían la plena igualdad de derechos entre cristianos viejos y nuevos y quienes, por el contrario, consideraban pertinente el apartamiento de los conversos de oficios y cargos públicos, el libro de Benzion NETANYAHU, Los orígenes de la Inquisición en la España del siglo XV, págs. 266-616. 
apartamiento de los judeoconversos de todo oficio concejil, y que supone un indudable precedente de los estatutos de limpieza de sangre.

Sofocada la revuelta toledana, el año 1450 marca el inicio de una recuperación de la autoridad política del Condestable. Y es en este momento cuando el rey Juan Il otorga, el 28 de agosto de 1450, en Arévalo, una Carta Real de confirmación de privilegios y de seguro a las comunidades judías de Castilla, que se sitúa en una línea similar a la Pragmática de Arévalo de 1443; en ella se confirma la autorización regia para el libre ejercicio de actividades económicas por parte de los judíos, así como el respeto a su culto religioso. Es probable que los recientes acontecimientos toledanos movieran a la corte castellana a una toma de postura decidida en favor de la población judía, quizá ante el temor a que las explosiones anticonversas pudieran derivar hacia los judíos. La Carta Real se conoce a través del traslado que de la misma se hizo el día 20 de octubre de 1450, en Medina del Campo, y a petición de Sem Tob Alpullate, vecino de Alcalá de Henares y procurador de las aljamas de los judíos de Castilla ${ }^{42}$. Se trata de un documento de enorme interés porque, a través de las bulas pontificias que en ella se insertan, se ofrece valiosa información acerca de las actitudes de la monarquía castellana y del pontificado hacia los judíos a lo largo de varios decenios del siglo XV, así como también sobre el posicionamiento de la comunidad judía en relación con la monarquía y en defensa de su autonomía organizativa.

La Carta Real de 1450 incorpora unas bulas de los papas Martín V y Eugenio IV, que son abiertamente favorables a los judíos. La primera bula de Martín V fue dada en Roma el 21 de septiembre de 1421, y en ella se reconoce a los judíos de Castilla el derecho a vivir entre los cristianos y se les autoriza a realizar todo tipo de actividades profesionales. La segunda bula de Martín V fue dada en Roma el 13 de febrero de 1428, a instancia de los procuradores de los judíos de España y Nápoles, que se quejaron de las predicaciones de ciertos frailes mendicantes y de otras órdenes, así como de los agravios que recibían por parte de cristianos. La bula de Eugenio IV fue dada en Bolonia el 24 de diciembre de 1436, a solicitud de los judíos de Castilla, y en ella se ampara a los judíos en el libre ejercicio de su religión y de sus costumbres.

La Carta Real de 1450 continúa señalando que algún tiempo después el papa Eugenio IV, a instancias de fray Rodrigo de Oña, había otorgado una bula contraria a los intereses de los judíos de Castilla, que había sido pregonada y ejecutada por el rey, estando en la ciudad de Toledo, en el año 1443; se trata de la bula «Super Gregem Dominicum», otorgada el 8 de agosto de 1442, y a la que ya se ha hecho referencia. Pero, debido a que esta bula daba lugar a muchos agravios y

42 Esta Carta se conserva en el Archivo Ducal de Medinaceli (Sevilla), Archivo Histórico, caja 2, núm. 21, y ha sido transcrita por Javier CASTAÑO GONZÁLEZ, «Las aljamas judías de Castilla a mediados del siglo XV: la Carta Real de 1450", en En la España Medieval, no 18 (1995), págs. 181-203 (en concreto, págs. 194-203), y por Fernando SUÁREZ BILBAO, El fuero judiego en la España Cristiana. Las fuentes jurídicas. Siglos V-XV, págs. 434-443. 
daños contra los judíos, que se iban a vivir fuera del reino y de los señoríos reales, lo que causaba daño en las rentas reales, y porque además no podían ser guardadas muchas de las disposiciones contenidas en la bula, por lo que muchas personas incurrían en sentencia de excomunión y en pena de pérdida de bienes, el rey ordenó suspender la ejecución de la bula, y suplicó al papa Eugenio IV, y después a Nicolás $\mathrm{V}$, que revocase la bula, a lo que este último terminó accediendo. De este modo, Nicolás V concedió el 2 de noviembre de 1447 la bula «Etsi Apostolice Sedis», por la que absolvía a todas las personas que hubieran incurrido en sentencia de excomunión y en censuras y penas por esta causa, y declaró quedar sin efecto la bula de Eugenio IV por la que se revocaban los privilegios, exenciones e inmunidades concedidos por los papas a los judíos, concediéndoles que pudieran disponer de jueces propios para sus pleitos internos y que sus médicos y cirujanos pudieran atender a cristianos. Finalmente, se prohíben predicaciones hostiles contra los judíos y se insta a los cristianos a que no les molesten ni vejen.

Como pone de manifiesto Javier Castaño, es especialmente significativo que, en el mismo año 1447 en que se otorgaba esta bula, el papa Nicolás V, a instancias del franciscano Juan de Capistrano ${ }^{43}$, reeditó para el reino de Nápoles la bula «Super Gregem Dominicum», encargando de su aplicación a los franciscanos. Que esto se haga en el mismo año en que se derogaba esta bula para el reino de Castilla sólo se explica por una decidida acción de la corte castellana en favor de la comunidad judía ${ }^{44}$.

Por todo ello, con el fin de que los judíos siguieran viviendo en sus reinos pacíficamente, como en tiempos de sus predecesores, y que no les fuera hecho ningún mal ni daño, considerando las leyes del reino, en especial lo ordenado por el rey Alfonso XI en las Cortes de Alcalá, y que la Iglesia ordena que sean tolerados y tratados con mansedumbre para propiciar su conversión al cristianismo, el rey Juan II confirmó las bulas apostólicas incorporadas a la carta real de 1450 y todas las otras bulas que los papas otorgaron en favor de los judíos antes de que el papa Eugenio IV diera la bula y breve contra los judíos solicitada por fray Rodrigo de Oña y revocada por Nicolás $V$. Y asimismo asegura que guardará y mandará guardar las leyes y ordenanzas dadas por él y sus antecesores en favor de los judíos.

Javier Castaño considera que la Carta Real de 1450 es más resultado de una decidida voluntad de las aljamas judías por buscar el amparo de la corona, que de un afán proteccionista del monarca y del Condestable. Así, afirma que la redacción de la Pragmática de Arévalo de 1443 y de la Carta Real de 1450 tiene lugar en dos momentos de dificultad para el valido, y que podrían interpretarse

${ }^{43}$ El franciscano italiano Juan de Capistrano (1386-1456), está considerado como uno de los grandes predicadores itinerantes del siglo XV. Actuó como legado pontificio en diversas ocasiones, obteniendo éxitos importantes en Bohemia y Hungría; predicó también en Baviera, Turingia, Silesia y Sajonia.

${ }^{44}$ Javier CASTAÑO GONZÁLEZ, «Las aljamas judías de Castilla a mediados del siglo XV: la Carta Real de 1450», pág. 188. 
como una respuesta de la corona al cuestionamiento de la situación legal de los judíos, a través de legislación pontificia o de la promulgación de ordenanzas concejiles. A este respecto, insiste en que la iniciativa de la redacción de estos textos legales parte de la comunidad judía ${ }^{45}$. Pero siendo plausible el planteamiento que hace Javier Castaño, no cabe tampoco duda de que, probablemente por interés político, la corona y el condestable Álvaro de Luna muestran una indudable voluntad por asegurar la integridad de las aljamas judías.

La Carta Real de 1450 marcó las directrices de la política castellana en relación con los judíos en los últimos años del reinado de Juan II. De este modo, cuando el 16 de julio de 1451 el concejo de Toledo aprobó unas ordenanzas discriminatorias para los judíos, los procuradores de la aljama elevaron sus quejas ante la justicia regia, y el 21 de febrero de 1452 el rey Juan II ordenaba al asistente real y a las autoridades concejiles toledanas que no hicieran pregonar sin licencia real ordenanzas o estatutos que fueran contra lo establecido en la Carta Real de 1450. Dos días después, el 23 de febrero de 1452, el concejo toledano declaraba nulas las cláusulas discriminatorias contra los judíos que se contenían en las ordenanzas de $1451^{46}$.

Con fecha de 26 de octubre de 1450 se conserva otro interesante documento, dado en esta ocasión en Medina del Campo a petición de Sem Tob Alpullate de Alcalá, procurador de las aljamas de los judíos de Castilla. Consiste en un traslado de un documento de 30 de agosto de 1450, de gran interés para el estudio de la figura del Rab Mayor de la Corte en los reinados de Juan I, Enrique III y Juan II, y que aporta también noticias relevantes acerca de las relaciones de la comunidad judía con el rey Juan II en los últimos años de su reinado ${ }^{47}$. En este documento se insertan ocho documentos de tiempos de Juan I, Enrique III y Juan II, entre los que a nosotros nos interesan en concreto dos de ellos, a los que se hace seguidamente referencia.

El mismo día de la emisión de la Carta Real de 1450, el 28 de agosto de este año, el rey Juan II revocaba el nombramiento que había realizado algún tiempo antes de Pedro de Luján, camarero real, como Juez Mayor y repartidor fiscal de las aljamas del reino, un nombramiento que se había hecho tras la muerte de Abraham Bienveniste, con la finalidad de situar al frente de la comunidad hebrea a una persona de la entera confianza del rey y del condestable Álvaro de Luna. La queja de los judíos se sustentaba en que este nombramiento rompía con la tradicional autonomía judía para el gobierno interno de la comunidad judía del reino, para juzgar en sus causas internas y para proceder a la distribución del «servicio y medio servicio» que los judíos debían satisfacer a la hacienda regia. En consecuencia, el

45 Javier CASTAÑO GONZÁLEZ, «Las aljamas judías de Castilla a mediados del siglo XV: la Carta Real de 1450», pág. 184.

46 Archivo Municipal de Toledo, cajón 5, núm. 3 (1453, febrero 23). Pilar LEÓN TELLO, Judíos de Toledo. Madrid. CSIC, 1979, 2 vols. (véase vol. I, doc. 54, págs. 458-465).

47 Este documento se conserva en el Archivo Municipal de Guadalajara, 136544, Cuaderno, y ha sido transcrito y estudiado por Macarena CRESPO ÁLVAREZ en su artículo titulado «El cargo de Rab Mayor de la Corte según un documento de Juan II fechado en 1450», págs. 179-198. 
rey cedía a perpetuidad a los judíos los oficios de juzgado mayor y menor y el repartimiento del «servicio y medio servicio», así como los repartimientos internos de las aljamas, concediéndoles un plazo de un año para elegir a un número de personas que consideraran idóneas para el desempeño de estos oficios, de entre los que el rey elegiría a la mitad para que se ocuparan del oficio durante toda su vida o durante el tiempo que las aljamas estimaran conveniente. Si en el plazo de un año no hubieran realizado la elección, serían los corregidores o alcaldes de las ciudades y villas quienes juzgarían, según la ley judía, los pleitos civiles y criminales, y quienes harían los repartos del «servicio y medio servicio». En definitiva, se atendía la demanda de las comunidades judías, aun cuando el rey se reservaba el derecho a nombrar a los oficiales, quizá con la finalidad de preservar la soberanía real sobre la comunidad judía. Las posiciones estaban claras: los judíos defendían a toda costa su autonomía de gobierno y la capacidad de autoadministrarse, en tanto que el monarca trataba de dejar sentado el principio de soberanía regia sobre dicha minoría ${ }^{48}$.

Dos días después, el 30 de agosto, el rey se dirige desde Arenas a los judíos del reino, en relación con una petición hecha por Sem Tob Alpullate, judío vecino de Alcalá de Henares, en su condición de procurador de las aljamas de los judíos de Castilla ${ }^{49}$. El representante de las aljamas judías había solicitado al monarca que durante el tiempo que mediara hasta la elección de las personas que se ocuparían de los oficios relativos al cargo de Juez Mayor, que fueran judíos quienes se encargaran de juzgar los pleitos de carácter interno, ya que los estaban juzgando cristianos, lo que era causa de irregularidades y abusos. El rey aceptó la solicitud y concedió un plazo de ocho días para que se procediera a la elección, dejando sentado el principio de que si en un año no se hubiera llevado a cabo la elección, los jueces elegidos en esos ocho días deberían abandonar el cargo, asumiendo

48 El principio de la pertenencia de los judíos al rey es muy antiguo. Así, desde la segunda mitad del siglo XII se extendió el concepto de servidumbre judía, que se sustentaba en escritos de los Padres de la Iglesia, y que si, desde un punto de vista jurídico-legal, constituía un signo inequívoco de la inferioridad de los judíos con respecto a los cristianos, a cambio les garantizaba la protección regia frente a otras distintas jurisdicciones. El concepto de servidumbre judía está presente en algunos textos canónicos y en numerosos documentos regios de las distintas entidades políticas de la Europa occidental y central, de forma que en la documentación alemana de la segunda mitad del siglo XII se hace referencia frecuentemente a los judíos como propiedad de la Cámara imperial; y algo similar sucede en la documentación regia francesa e inglesa. En los reinos hispanos, el concepto de servidumbre judía aparece expresado por primera vez en el fuero de Teruel (1177), en el que se afirma que «los judíos son siervos del rey y pertenecen al tesoro real»; del mismo modo, la mayor parte de los fueros de la familia Cuenca-Teruel indican de forma expresa en alguna de sus disposiciones que las caloñas por muerte o lesiones causadas a judío corresponden a la corona, por su condición de propiedad regia. Ya en el siglo XIII, el Libro de los Fueros de Castilla sentó el principio de que los judíos pertenecían al rey aunque pudieran estar sujetos a la autoridad de señores laicos o eclesiásticos: «magüer que sean so poder de ricos omnes, o con sus cavalleros, o con otros omnes, o so poder de monesterios, todos deven ser del rey en su goarda e para su servyçio».

49 Sem Tob Alpullate es un personaje relevante de la comunidad judía castellana de mediados del siglo $\mathrm{XV}$, en particular entre los años 1445 y 1455, cuando tuvo una destacada proyección pública como representante de las aljamas judías del reino, en un momento delicado por la muerte de Abraham Bienveniste, quien había marcado la trayectoria de la comunidad judía castellana durante varios decenios. 
sus funciones los corregidores, alcaldes y justicias de cada ciudad, ocupándose los contadores mayores del rey del reparto de los tributos.

Estos dos documentos de agosto de 1450 son claramente expresivos de la voluntad de acuerdo existente entre la corona y las aljamas judías. Si las aljamas sabían bien que su principal valedor era el monarca, en un momento especialmente delicado por la pugna que el Condestable mantenía con la levantisca nobleza, el rey consideraba a los judíos como un aliado seguro en su defensa del principio de la autoridad monárquica.

\section{CONCLUSIONES}

De todo lo expuesto hasta aquí, considero que es posible extraer varias conclusiones:

1‥- El reinado de Juan Il es un magnífico ejemplo de cómo a lo largo de toda la Edad Media el destino de la comunidad judía castellana estuvo íntimamente asociado a la institución monárquica, de forma que los momentos de debilitamiento de la autoridad regia estuvieron marcados por el acoso a los judíos, en tanto que los años de fortalecimiento del poder central permitieron un reforzamiento de la comunidad hebrea. De este modo, a lo largo de todo el reinado de Juan II los altibajos en la condición legal de los judíos coinciden con los altibajos en el control de la situación política por parte del condestable Álvaro de Luna. Por ello, a lo largo de toda la Plena y Baja Edad Media se mantuvo la conciencia de que la figura del rey era la que posibilitaba la continuidad de una comunidad con religión distinta a la de la mayoría, y los judíos, que no eran ajenos a esta realidad, veían como algo lógico y natural la fidelidad a la figura del monarca.

$2^{a}$.- En el reinado de Juan II es fácil apreciar dos etapas perfectamente diferenciadas en lo que respecta a la legislación relativa a los judíos: la etapa, correspondiente a la minoría del monarca, marcada por la Pragmática de Valladolid de 1412, claramente conculcadora de los derechos de los judíos, y la etapa correspondiente al reinado efectivo de Juan II, caracterizada en general por la protección legal a las comunidades judías y la estabilidad, salvo en momentos determinados coincidentes con la pérdida de poder por parte del Condestable; la protección legal hacia la comunidad judía tiene su expresión más patente en la Pragmática de Arévalo de 1443 y en la Carta Real de 1450.

$3^{\text {a }}$-- Son escasísimas las referencias a los judíos en los cuadernos de Cortes de tiempos de Juan II de Castilla, de forma que en las cerca de treinta reuniones de Cortes celebradas a lo largo de su reinado, tan sólo en las de Burgos de 1430 y en las de Madrigal de 1438 se hace referencia explícita a los judíos. Esto puede deberse, en primer lugar, a que tras las persecuciones de 1391 y las predicaciones de fray Vicente Ferrer el número de judíos y su peso cualitativo en el conjunto de la sociedad castellana había disminuido tan considerablemente que habrían dejado de 
constituir un foco de atención para los procuradores de las ciudades y villas. $Y$, en segundo lugar, es posible también que los procuradores de las ciudades y villas en Cortes consideraran que el Ordenamiento de Valladolid de 1412 estaba aún en vigor y que, por tanto, no era necesario insistir en la aprobación de disposiciones concretas relativas a los judíos, ya que el Ordenamiento contenía todo aquello que había sido reclamado insistentemente en las Cortes a lo largo de los siglos XIII y XIV.

4‥- La figura del valido Álvaro de Luna se revela como la del más firme defensor de los judíos, de forma que los períodos en los que ejerce su poder sin cortapisas es cuando se promulga la legislación más favorable para los judíos. En el primer decenio del reinado efectivo de Juan II, los judíos pasaron de constituir una comunidad absolutamente precaria a recobrar buena parte de su antigua pujanza económica y de su posición social. Del mismo modo, no cabe duda de que en la política decididamente projudía de Álvaro de Luna tuvo una influencia decisiva Abraham Bienveniste, cabeza de la comunidad judía castellana y uno de los principales asesores financieros de la corona.

5‥- Las razones que mueven a Juan II de Castilla a proteger legalmente a los judíos del reino están expresadas de forma nítida en la Carta Real de 1450: a) La obediencia a la Iglesia, que mantiene el principio agustiniano de tolerancia hacia los judíos con el fin de que, mediante la persuasión y la mansedumbre, llegaran un día a la conversión. En esta línea se situarían las bulas expedidas por los papas Martín V y Eugenio IV, que se insertan en el texto de la Carta Real de 1450, y en las que es fácil apreciar un decidido proteccionismo hacia los judíos, aun cuando sin renunciar al objetivo de su conversión al cristianismo. b) La tradición de las leyes del reino, que aseguraban la protección de los judíos, y en particular del Ordenamiento de Alcalá de 1348, en el que se había buscado una salida para garantizar la permanencia de los judíos de Castilla, en un momento en el que el rey Alfonso XI sufría las presiones derivadas de las disposiciones acordadas en el Concilio de Vienne de 1311-1312 y en el Concilio de la provincia eclesiástica de Santiago celebrado en Zamora en los años 1312-1313.

A estas dos razones habría que añadir el deseo de proteger a unos súbditos que seguían siendo de importancia fundamental para el desarrollo de tareas hacendísticas y de gobierno, así como el interés por evitar la mala imagen que para el principio de la autoridad monárquica se derivaría de unos ataques impunes contra unos súbditos directos del monarca.

6a.- Tanto la corona como los judíos manifiestan una decidida voluntad de centralización en la organización de la comunidad judía castellana, deseable por parte de la corona porque garantiza un mayor control de las aljamas, y deseable también por la minoría judía porque, a través del Rab Mayor de la Corte o del procurador de las aljamas, era más fácil canalizar la defensa de sus intereses y asegurar la protección regia. 
$7^{\text {a }}$ - Las bulas pontificias a las que se hace referencia en este trabajo permiten comprobar cómo la actitud de los Papas en la primera mitad del siglo XV en relación con los judíos, con el único paréntesis que supone el pontificado de Benedicto XIII, seguía estando acorde con la que podría denominarse postura oficial de la Iglesia, que entronca con el pensamiento agustiniano: reprobación del judaísmo desde el punto de vista teológico, pero defensa de la tolerancia hacia la persona de los judíos, expresada en la libertad de culto y de residencia entre los cristianos, y en la garantía de protección hacia sus personas y bienes, con la esperanza de que un día se convirtieran al cristianismo. 